\title{
PENGARUH LOYALITAS, PRESTASI KERJA, DAN SENIORITAS TERHADAP PROMOSI JABATAN PADA PT PACTO LTD DI BALI
}

\author{
Azyyati Umi Hariyanti ${ }^{1}$ \\ I Gusti Ayu Ketut Giantari² \\ ${ }^{1,2}$ Fakultas Ekonomi dan Bisnis Universitas Udayana (Unud), Bali, Indonesia \\ e-mail : umiazyyati@gmail.com
}

\begin{abstract}
ABSTRAK
Loyalitas, prestasi kerja dan senioritas telah diketahui memiliki dampak terhadap promosi jabatan. Penelitian bermaksud untuk mengidentifikasi korelasi tersebut pada 77 karyawan di PT. PACTO Ltd di BALI melalui teknik sampling jenuh dan pengambilan data dengan wawancara serta kuesioner. Analisis regresi linier berganda adalah teknik yang dipakai pada penelitian dan ditemukan loyalitas, prestasi kerja, dan senioritas berkorelasi positif dengan promosi jabatan. Para pekerja diharapkan memiliki kerja sama yang baik dengan karyawan lainnya dan terus meningkatkan kemampuan sehingga segala tugas dari perusahaan dapat dilakukan dengan sebaik mungkin. Pihak manajamen sebaiknya lebih mempertimbangkan masa kerja karyawan, sehingga semua karyawan senior mempunyai peluang yang sama untuk dipromosikan pada jabatan yang lebih tinggi.
\end{abstract}

Kata kunci: loyalitas, prestasi kerja, senioritas, promosi jabatan

\section{ABSTRACT}

Loyalty, work performance and seniority have known to have an impact on promotion. This study intends to identify these correlations in 77 employees at PT. PACTO Ltd in BALI through saturated sampling techniques and data collections with interviews and questionnaires. Multiple linear regression analysis is a technique use in research and found loyalty, work performance, and seniority positively correlated with job promotion. Employees are expected to have good cooperation with other employees and continue to improve their abilities so that all tasks from the company can be done as well as possible. The management should better consider the employee's tenure, so that all senior employees have equal opportunities to be promoted to higher positions.

Keywords: loyalty, job performance, seniority, job promotion 


\section{PENDAHULUAN}

Pariwisata adalah sektor usaha unggul yang diharapkan mampu menunjang perbaikan situasi ekonomi Negara, melalui pengaruhnya terhadap Ekonomi, Sosial, maupun Lingkungan secara positif(Maulana, 2016). Semakin meningkatnya orangorang melakukan perjalanan wisata maka diperlukan juga peningkatan dari segi pelayanan tour and travel, dengan demikian perusahaan juga harus mengoptimalkan sumber daya manusianya yang dimiliki. Dengan baiknya kualitas sumber daya, karyawan akan memiliki kinerja yang baik juga dan mampu menunjang kesuksesan perusahaan melalui motivasi yang diberikan pimpinan perusahaan, salah satunya dalam bentuk promosi.

Promosi jabatan adalah peningkatan jabatan seorang karyawan menjadi karyawan tetap dan dibarengi dengan peningkatan hak, kewajiban dan pendapatannya (Hasibuan, 2014:175). Menurut Siagian (2012:170) pada umumnya perusahaan atau organisasi menggunakan prestasi kerja dan senioritas dalam mempertimbangkan seseorang untuk dipromosikan. Naveed et al. (2011) menyatakan bahwa promosi dapat membuat peningkatan dalam gaji karyawan serta dalam otoritas dan kontrol, dalam hal ini akan membantu pesaing untuk mengidentifikasi karyawan yang paling produktif di dunia bisnis. Pada saat yang sama karyawan sedang diakui oleh organisasi mereka sendiri. Karyawan sendiri merasa menjadi kontributor yang efektif dan dengan demikian akan lebih puas dengan pekerjaan mereka. Menurut Tuwei et al. (2013) sebelum perusahaan mempromosikan seorang karyawan untuk posisi tertentu, perusahaan memastikan bahwa orang tersebut mampu menangani tanggung jawab ditambah penyaringan 
karyawan dengan cara wawancara dan tes dan memberi mereka pelatihan atau pengalaman kerja. Perolehan penilaian performa kerja bisa memastikan seorang pegawai mendapat kenaikan jabatan, dengan cara manajemen menilik seberapa baik performa kerja seorang pegawai dalam perusahaan (Fernandes dan Vijay, 2012). Terlepas dari rasa puas seorang pegawai pada pekerjaannya, kenaikan jabatan bisa berlaku untuk menilik kepuasan kerja pegawai (Khan et al., 2013). Kenaikan jabatan merupakan penugasan seorang pegawai ke jabatan yang lebih tinggi dari pekerjaan sebelumnya (Malik et al., 2012).

Loyalitas menandakan pengabdian seseorang terhadap objek tertentu seperti sekelompok orang ataupun tugas yang diberikan. Loyalitas karyawan sendiri tidak dapat diukur melalui jawaban pertanyaan langsung, asumsi apakah karyawan bekerja secara efektif ataukah tidak, tidak bisa dinilai melalui asumsi (Iqbal et al., 2015). Loyalitas merupakan suatu sikap rela berkorban demi kepuasan dari pihak lain, yang muncul oleh adanya keinginan untuk setia dan memperbaiki pekerjaan, kelompok, atasan maupun perusahaannya. Seseorang dengan sikap tersebut cenderung bekerja tanpa menghiraukan berapapun imbalannya namun tetap memberikan hasil kerja yang menjadi prestasi kerjanya (Safitri, 2015). Hubungan harmonis antar pegawai merupakan hal penting untuk mempertahankan loyalitas pegawai (Suharti dan Dendy, 2012). Tingginya rasa loyalitas tumbuh seiring kondisi dan perlakuan perusahaan terhadap karyawan yang kondusif. Introspeksi akan faktor penyebab menjadi sesuatu yang perusahaan wajib lakukan ketika loyalitas karyawannya rendah atau mengalami penurunan (Heryati, 2016). Secara tradisional, loyalitas karyawan berarti kemampuan untuk tinggal dengan organisasi 
dalam jangka panjang (Khuong et al., 2013). Sebuah bisnis dapat mengelola karyawan secara biasa saja tetapi karyawan yang kompeten dapat mendorong bisnis memperoleh pencapaian pada tingkat yang lebih tinggi. Demikian pula, karyawan dengan kemampuan kerja yang tidak baik akan membawa akibat yang tidak baik bagi keberlangsungan perusahaan. Ketatnya pasar tenaga kerja menjadi semakin penting dan menantang bagi perusahaan untuk menjaga dan mengembangkan loyalitas karyawan (Wan, 2013). Melihat hal ini, perusahaan sebaiknya mampu untuk membentuk iklim kerja yang aman dan nyaman, demi loyalitas kerja serta perasaan berhasil tiap individu karyawan (Ong et al., 2014).

Prestasi kerja merupakan hasil kerja karyawan berbentuk barang atau jasa, kualitas atau kuantitas, maupun perilaku dalam keseluruhan kegiatan yang dilaksanakan sehingga mempersembahkan nilai yang baik untuk mewujudkan tujuan perusahaan (Pratama dkk., 2013). Performa kerja pegawai sangat berguna pada perusahaan agar tercapai harapan perusahaan (Matasik dkk., 2017). Untuk menaikkan kinerja pegawai, perusahaan perlu untuk berinvestasi dalam membangun sumber daya pekerjaan yang lebih formal ( Breevaart dan Arnold, 2015). Penilaian prestasi kerja merupakan suatu bentuk tanggapan dari berbagai suatu hal termasuk keahlian, keletihan, kekurangan dan potensinya, yang bermanfaat bagi karyawan dalam rangka penentuan tujuan, rencana, jalur dan pengembangan karirnya. Bentuk penilaian ini akan menjadi motivasi kemajuan seseorang di masa mendatang. Penilaian prestasi kerja dalam suatu perusahaan atau organisasi adalah jawaban sukses atau tidak tujuan perusahaan atau organisasi yang telah ditentukan. Bagi seorang manajer, penilaian prestasi kerja menjadi bentuk 
informasi untuk mengetahui kemampuan karyawannya merampungkan tugas kewajiban dan tanggung jawab yang diberikan. Melalui prosedur penilaian tertentu akan diketahui seberapa baik karyawan mampu menyelesaikan pekerjaannya. Penilaian prestasi kerja turut membantu perusahaan melihat kekurangan maupun potensi seseorang terkait target promosi jabatan (Andriani, 2018). Menurut Prabowo dkk. (2016), prestasi kerja merupakan bahan pertimbangan perusahaan untuk memberikan promosi. Evaluasi prestasi kerja dari karyawan diperlukan untuk mewujudkan implementasi yang adil dan obyektif. Apabila sistem penilaian tersebut tidak tersusun sedemikian rupa, hilangnya kesempatan dari karyawan yang tidak ikut dipromosikan tentu akan menyebabkan turunnya motivasi dan prestasi kerja. Metode penilaian prestasi kerja merupakan yang paling sering digunakan untuk menilai potensi promosi dan memperoleh jabatan yang lebih tinggi, seperti yang disebutkan oleh Anyim dkk. (2011). Manajemen menilai seberapa besar prestasi pekerjaan dari karyawan perusahaan, dimana hasil penilaian tersebut turut mengambil andil penting dalam menentukan dipromosikan atau tidaknya seorang karyawan.

Sejumlah peneliti turut menelusuri pengaruh dari prestasi kerja terhadap promosi jabatan. Prestasi kerja, memiliki kaitan erat dengan promosi jabatan, dimana semakin tinggi prestasi kerja, potensi bagi karyawan tersebut untuk memperoleh promosi akan semakin meningkat (Pratimi, 2006). Hal ini berbeda dengan pernyataan oleh Elfianto (2015) yang mengatakan prestasi kerja tidak berdampak positif terhadap promosi jabatan. 
Penelitian terdahulu oleh Pratimi (2016) menyatakan prestasi kerja mempunyai pengaruh positif pada promosi jabatan. Namun prestasi kerja mempunyai pengaruh yang negatif dinyatakan oleh penelitian Elfianto (2015).

Senioritas muncul secara seiring dengan semakin lamanya seseorang bekerja dan dengan begitu, menduduki pangkat yang lebih tinggi dibandingkan bawahannya (Andhara dkk., 2015). Senioritas merupakan salah satu aspek yang dinilai perusahaan dalam memberikan program promosi jabatan. Tingkat senioritas karyawan bersifat indikatif terhadap kesuksesan perusahaan maupun organisasi, semakin tinggi jabatan/tingkat senioritasnya menunjukkan masa kerjanya yang lebih lama (Purwaningsih dan Betty, 2017). Beberapa organisasi memakai senioritas untuk menentukan siapa pegawai yang harus di phk ketika perampingan pegawai terjadi (Sobieralski dan Cynthia, 2012). Semua pegawai dalam divisi akan mendapatkan gaji yang bervariasi sesuai dengan senior dan kinerjanya (Gupta dan Jason, 2014). Seiring dengan bertambahnya pengalaman dan kemampuan seorang karyawan untuk berkembang, karyawan akan memiliki rasa betah dan keinginan untuk bertahan di perusahaan, salah satunya melalui promosi ke jabatan yang lebih tinggi. Namun demikian, tingkat senioritas yang dipertimbangkan hanya berdasarkan pada lama seorang karyawan bekerja di suatu perusahaan, seringkali menjadi permasalahan, yaitu promosi yang dilaksanakan semata-mata hanya berdasarkan senioritas tanpa turut mempertimbangkan evaluasi terhadap kualitas. Sistem penilaian dan penetapan promosi seperti ini akan berimplikasi buruk terhadap perusahaan maupun bagian-bagian lain dari perusahaan, karena badan tersebut dipimpin oleh pribadi yang rendah secara kompetensi dan kualitasnya 
(Muamarizal dkk., 2015). Senioritas selain dipergunakan sebagai cara untuk kenaikan jabatan, juga dipergunakan sebagai cara untuk menetapkan kenaikan gaji pegawai (Manullang, 2011:10).

Menurut penelitian Mandiangan dan Agoes (2015) dan Sari (2015), senioritas berhubungan positif dengan promosi jabatan. Namun pernyataan yang berkebalikan disampaikan oleh Marion dkk., (2012) yang menyatakan bahwa senioritas atau nenkojoretsu tidak berpengaruh terhadap promosi jabatan.

Penelitian ini dilakukan pada karyawan tetap PT. Pacto Ltd yang berjumlah 77 orang. TTG Asia Awards Night 2011 menetapkan perusahaan ini sebagai market leader, dan menganugrahkan kepada PT. Pacto Ltd sebagai “Agen Wisata Terbaik di Indonesia" dalam tiga tahun berturut - turut.

\section{Tabel 1.}

Jumlah Promosi Jabatan Karyawan PT. Pacto Ltd di Bali

\begin{tabular}{cccc}
\hline Tahun & $\begin{array}{c}\text { Jumlah Karyawan Tetap } \\
\text { (orang) }\end{array}$ & $\begin{array}{c}\text { Jumlah Promosi } \\
\text { (orang) }\end{array}$ & Persentase \\
\hline 2013 & 80 & 1 & 12,5 \\
2014 & 84 & 2 & 23,8 \\
2015 & 82 & 2 & 24,4 \\
2016 & 82 & 2 & 24,4 \\
2017 & 87 & 3 & 34,5 \\
2018 & 77 & 1 & 13 \\
\hline
\end{tabular}

Sumber : Bagian Human Resources \& General Affair Department PT. Pacto Ltd di Bali, 2018.

Pelaksanaan promosi jabatan tahun 2013 sampai tahun 2018 mendapati peningkatan dan penurunan, seperti yang disampaikan dalam Tabel 1. Tahun 2013 persentase karyawan untuk dipromosikan lebih kecil dibanding dengan tahun lainnya yaitu sebesar 12,5\%. Pada tahun 2015 dan 2016 persentase karyawan untuk dipromosikan sama yakni $24,4 \%$. Persentase promosi jabatan tertinggi terdapat pada tahun 2017 sebesar $34,5 \%$ dan di tahun 2018 mengalami penuruan yang drastis 
yakni sebesar 13\%. Setiap tahunnya PT. Pacto Ltd di Bali melakukan promosi jabatan kepada karyawannya dan tidak pernah mencapai lebih dari 10 orang.

Kurang efektifnya sistem promosi jabatan yang dilakukan oleh perusahaan pada faktor prestasi kerja disebabkan masih terdapat karyawan yang belum paham dengan uraian pekerjaannya sehingga kinerja yang dihasilkan kurang maksimal dan tidak memenuhi persyaratan untuk dipromosikan. Banyak juga karyawan yang sering absen kerja, kurangnya rasa tanggungjawab terhadap pekerjaannya dan hal tersebut mencermikan sikap yang tidak loyal terhadap perusahaan. Pada faktor senioritas terjadi karena pihak manajemen perusahaan tidak memberi peluang secara merata terhadap karyawan yang memiliki masa kerja terlama.

Berdasarkan latar permasalahan tersebut, maka pokok permasalahan yang akan diteliti melalui tulisan ini adalah loyalitas, prestasi kerja, dan senioritas terhadap promosi jabatan. Dari rumusan masalah tersebut maka tujuan dilaksanakannya penelitian yaitu untuk menilai loyalitas, prestasi kerja, dan senioritas terhadap promosi jabatan.

Secara teoriti perolehan yang didapatkan dari penelitian diharapkan menjadi studi awalan sebagai penambah referensi mengenai manajemen sumber daya manusia serta dapat memperkaya wawasan mengenai loyalitas, prestasi kerja, senioritas serta promosi jabatan. Secara praktisnya, temuan dalam penelitian ini mampu diposisikan sebagai alternatif solusi yang mampu diterapkan perusahaan.

Seorang karyawan merupakan sumber daya yang paling vital dan penting untuk perusahaan miliki (Thanos dkk., 2015). Memiliki strategi untuk mempertahankan dan menjaga kesetiaan mereka adalah tantangan yang perusahaan 
harus hadapi, maka karyawan bisa memberikan hasil mereka yang paling efektif untuk perusahaan.

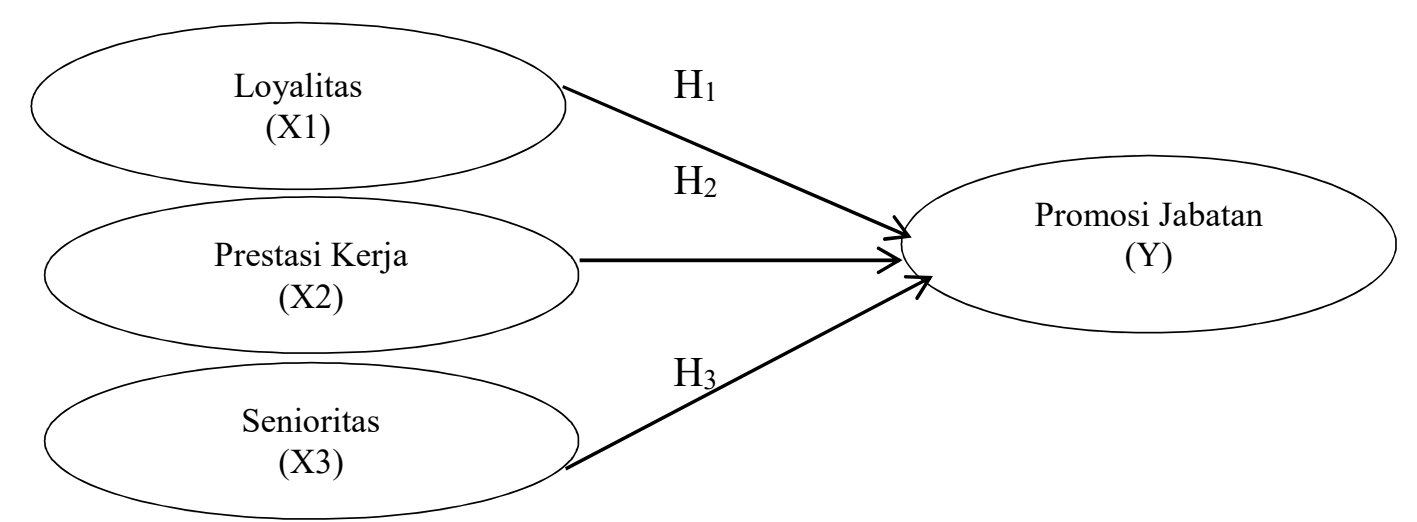

Gambar 1. Kerangka Konseptual

Loyalitas karyawan adalah sebuah hasil yang sangat penting untuk mempertahankan karyawan. Salah satu persyaratan promosi yang ditetapkan perusahaan yaitu loyalitas, karena dengan tingginya tingkat kesetiaan seseorang terhadap perusahaan, memungkinkan karyawan untuk memberikan hasil kerja terbaik dalam rangka mencapai tujuan dari perusahaan tersebut (Aryani dkk., 2010).

Loyalitas merupakan sikap rasa memiliki dan tanggungjawab seseorang terhadap suatu organisasi, perusahaan, benda maupun lainnya. Siswanto (dalam Saputra dkk., 2016) mengungkapkan hubungan antar pribadi, taat pada peraturan, tanggung jawab, rasa memiliki, dan kecintaan terhadap pekerjaan merupakan indikator untuk mengukur loyalitas. Loyalitas karyawan memberikan pengaruh terhadap promosi jabatan, terkait dengan rasa tanggung jawab, kesanggupan dalam berkorban, dan rasa turut memiliki perusahaan, menimbulkan keinginan untuk memberikan yang terbaik pada tempatnya bekerja (Hamzah dkk., 2013). Loyalitas 
seorang pegawai mempunyai korelasi dengan kenaikan jabatan, yang artinya loyalitas kerja akan mendukung kemungkinan memperoleh promosi jabatan disampaikan oleh Penelitian Soegandhi dkk. (2013).

Menurut penelitian Mandiangan dan Agoes (2015) loyalitas memiliki pengaruh yang segnifikan terhadap kenaikan jabatan. Loyalitas dan komitmen seorang pegawai berasosiasi langsung dengan promosi jabatannya disimpulkan oleh Turkyilmaz et al. (2011). Hal senada disampaikan oleh Prabudi (2015), dimana loyalitas karyawan memiliki pengaruh yang positif terhadap prestasi kerja. Tidak berbeda dibandingkan dengan yang telah diungkapkan oleh Mirayanti (2015) loyalitas berkorelasi positif dengan promosi jabatan pada Kantor Sekretariat Kabupaten Tolitoli, secara signifikan. Merangkum beberapa temuan sebelumnya, penulis mengembangkan hipotesis, yaitu:

$\mathrm{H}_{1}$ : Loyalitas berpengaruh positif terhadap promosi jabatan.

Dar et al. (2011) melihat prestasi kerja sebagai kesanggupan individu untuk menyelesaikan tugas yang diberikan kepadanya. Cressida dkk., (2013) menemukan bahwa prestasi kerja memiliki andil terhadap promosi jabatan, yang dapat dinilai melalui kualitas, kuantitas dan ketepatan waktu dalam memproses suatu pekerjaan. Menurut penelitian oleh Sasmita dan Ni (2016) prestasi kerja berimplikasi positif terhadap promosi jabatan karyawan. Penelitian oleh Medhiantari dan Made (2014) menyatakan bahwa terdapat implikasi yang bermakna secara simultan dan parsial dari prestasi kerja terhadap kesempatan promosi jabatan. Menurut penelitan Hayati (2015) variabel yang paling besar implikasinya terhadap keputusan promosi jabatan pegawai adalah variabel prestasi kerja. Siska dan Suryalena (2017) dalam 
penelitiannya menemukan adanya pengaruh pretasi kerja terhadap promosi jabatan, dimana semakin baik prestasi kerja semakin tinggi kemungkinan seseorang untuk dipromosikan. Beberapa teori tersebut menjadi dasar pengujian hipotesis yang penulis hendak ajukan, yaitu.

$\mathrm{H}_{2}$ : Prestasi kerja berpengaruh positif terhadap promosi jabatan.

Senior merupakan asal kata dari senior, yang berposisi sebagai tingkat parameter dari suatu terhadap suatu yang sepadan. Senior selalu dikaitkan dengan antonima dari dari junior (Sari, 2015). Penelitian Edmondson (2012) mendapatkan hasil bahwa senioritas merupakan faktor utama dalam promosi jabatan di Amerika Serikat menempatkan durasi hubungan sebagai faktor penting dalam mempromosikan karyawannya. Yeh dan Jiin (2012) menyatakan bahwa, faktor senioritas cenderung lebih berpotensi dalam menentukan kesempatan promosi, dibandingkan dengan kijerka. Menurut Andhara dkk. (2015) ada pengaruh yang bersifat signifikan dari senioritas karyawan terhadap promosi jabatan. Menurut Purwaningsih dan Betty (2017) senioritas berpengaruh terhadap promosi jabatan. Jadi semakin senior atau semakin lama masa kerja seseorang dalam suatu perusahaan maka semakin tinggi untuk mendapat promosi jabatan. Teori-teori dari penelitian tersebut menjadi dasar pengajuan hipotesis yang penulis hendak uji, yaitu.

$\mathrm{H}_{3}$ : Senioritas berpengaruh positif terhadap promosi jabatan.

\section{METODE PENELITIAN}

Analisis kuantitatif digunakan pada proses penelitian. Fungsi dari analisis kuantitatif yaitu untuk melihat kaitan antara variabel dengan obyek penelitian lebih 
bersifat sebab dan akibat (kausal), sehingga terdapat independent dan dependent variable (Sugiyono, 2015:14). Adapun variabel penelitian ini adalah loyalitas (X1), prestasi kerja (X2), senioritas (X3), dan promosi jabatan (Y). Perusahaan PT. Pacto Ltd di Bali, berlokasi di Jalan By Pass Ngurah Rai Sanur no 378, Denpasar Selatan, Sanur, Denpasar, Bali adalah lokasi penelitian ini dilakukan. Subjek penelitian ini adalah karyawan PT. Pacto Ltd di Bali. Objek penelitian meliputi loyalitas, prestasi kerja, senioritas dan promosi jabatan.

Populasi penelitian yaitu seluruh karyawan tetap PT. Pacto Ltd di Bali sejumlah 77 orang, yang ditetapkan melalui metode sensus atau sampling jenuh. Data kualitatif dan kuantitatif adalah data yang dipakai pada penelitian. Data yang dicari atau diambil serta merta dari lapangan merupakan data primer penelitian ini dan data sekunder berasal dari media perantara atau dokumen. Data dikumpulkan dari hasil wawancara dan pengisian kuesioner.

Uji validitas dapat digunakan untuk mengukur alat ukur, dalam konteks ini berarti mengukur sejauhmana kesesuaian pernyataan pada sebuah kuesioner untuk menaksir variabel yang hendak diteliti (Sugiyono 2015:172). Uji reliabilitas dipakai penelitian untuk menilai koherensi alat ukur dalam penggunaannya. Instrument akan dikatakan reliabel bila menghasilkan data yang sama ketika mengukur objek yang sama (Sugiyono, 2015:183).

Analisis statistik deskriptif, seperti yang diterapkan dalam penelitian ini, menilai data melalui menggambarkan atau mendeskripsikan data terkumpul tanpa menciptakan simpulan yang berlaku umum atau generalisasi (Sugiyono, 2015:207), untuk menilai pengaruh atau suatu keterkaitan dari sebuah variabel terikat dengan 
sejumlah variabel bebas, analisis regresi linier berganda yang dimanfaatkan (Suyana Utama, 2012:77), untuk memperoleh model regresi yang bagus dan terlepas dari penyimpangan, uji asumsi klasik digunakan (Ghozali, 2013:57), untuk memperlihatkan layaknya regresi linier berganda menjadi alat analis untuk mengukur dampak variabel independent dengan variabel dependen, pengujian goodness of fit (uji F) yang dipakai penelitian (Ghozali, 2013:88), untuk menilai dampak dari tiap - tiap variabel bebas dengan variabel terikatnya dengan cara parsial pengujian secara parsial yang dipergunakan (Ghozali, 2013:88) dan untuk mengetahui besar sumbangan variabel bebas dengan variabel terikat dan menilai keakuratan alat analisis, koefisien determinasi $\left(\mathrm{R}^{2}\right)$ digunakan.

\section{HASIL DAN PEMBAHASAN}

Ditampilkan dalam Tabel 2. dengan karakteristik Responden penelitian berjumlah 77 orang, gender dipakai untuk mengetahui gender dari partisipan penelitian dan yang menjadi partisipan adalah laki - laki 50 personil dan perempuan 27 personil, rentang usia dipakai untuk mengetahui usia responden penelitian dan rentang usianya adalah 26 - 30 tahun 12 personil, 31 - 35 tahun 19 personil, $36-$ 40 tahun 18 personil, 41 - 45 tahun 7 personil, 46 - 50 tahun 10 personil, dan $51-$ 50 tahun 11 personil.

Memperlihatkan dari Tabel total responden yang memiliki gender laki - laki paling menonjol adalah sejumlah 50 orang $(64,94 \%)$ sebaliknya responden yang memiliki gender perempuan sejumlah 27 orang $(35,06 \%)$. Jumlah responden pada tingkat umur 26-30 tahun sejumlah 12 orang (15,58\%), umur 31-35 tahun sejumlah 19 orang $(24,68 \%)$, umur 36-40 tahun sejumlah 18 orang $(23,38 \%)$, umur 41-45 
tahun sejumlah 7 orang (9,09\%), umur 46-50 tahun sejumlah 10 orang (12,99\%) dan umur 51-55 tahun sejumlah 10 orang (14,29\%).

Tabel 2.

Karakterisik Responden

\begin{tabular}{cccc}
\hline Nomor & Gender & Orang & Jumlah \\
1 & Laki - laki & 50 & Persen \\
2 & Perempuan & 27 & 64.94 \\
& Jumlah & 77 & 35.06 \\
Nomor & Rentang Usia (Tahun) & & $\mathbf{1 0 0}$ \\
1 & $26-30$ tahun & 12 & \\
2 & $31-35$ tahun & 19 & 15.58 \\
3 & $36-40$ tahun & 18 & 24.68 \\
4 & $41-45$ tahun & 7 & 23.38 \\
5 & $46-50$ tahun & 10 & 9.09 \\
6 & $51-55$ tahun & 11 & 12.99 \\
& Jumlah & $\mathbf{7 7}$ & $\mathbf{1 0 0}$ \\
\hline
\end{tabular}

Sumber : data diproses, 2018.

Memiliki hasil korelasi total lebih besar dari nol koma tiga menggambarkan bahwa seluruh butir pertanyaan pada variabel promosi jabatan, loyalitas, prestasi kerja dan senioritas telah memenuhi kriteria validitas hasil uji validitas pada tabel 3, sehingga layak digunakan sebagai instrumen pengumpulan data penelitian.

Memiliki hasil korelasi total lebih besar dari nol koma tiga menggambarkan bahwa seluruh butir pertanyaan pada variabel promosi jabatan, loyalitas, prestasi kerja dan senioritas telah memenuhi kriteria validitas hasil uji validitas pada tabel 3, sehingga layak digunakan sebagai instrumen pengumpulan data penelitian.

Dinyatakan instrument penelitian telah sesuai kriteria reliabilitas karena perolehan reliabilitas instrument pada Tabel memperlihatkan nilai alpha cronbach's pada variabel promosi jabatan, loyalitas, prestasi kerja dan senioritas lebih besar dari nol koma enam. 
Tabel 3.

Uji Validitas Instrumen

\begin{tabular}{lccc}
\hline Variable & $\begin{array}{c}\text { Butir } \\
\text { Pernyataan }\end{array}$ & $\begin{array}{c}\text { Korelasi } \\
\text { Total }\end{array}$ & Ket. \\
\hline Promosi jabatan & Y1 & 0,684 & Val \\
& Y2 & 0,799 & Val \\
& Y3 & 0,825 & Val \\
& Y4 & 0,758 & Val \\
Loyalitas & Y5 & 0,841 & Val \\
& X1.1 & 0,833 & Val \\
& X1.2 & 0,780 & Val \\
& X1.3 & 0,614 & Val \\
Prestasi kerja & X1.4 & 0,691 & Val \\
& X1.5 & 0,642 & Val \\
& X2.1 & 0,866 & Val \\
& X2.2 & 0,878 & Val \\
& X2.3 & 0,852 & Val \\
Xenioritas & X2.4 & 0,809 & Val \\
& X2.5 & 0,897 & Val \\
& X3.1 & 0,814 & Val \\
& X3.2 & 0,810 & Val \\
\hline
\end{tabular}

Sumber : data diproses, 2018.

Tabel 4.

Uji Reliabilitas Instrumen

\begin{tabular}{|c|c|c|c|c|c|}
\hline \multirow[t]{2}{*}{ Nomor } & \multirow[t]{2}{*}{ Variabel } & \multirow[t]{2}{*}{ Item } & \multicolumn{2}{|c|}{ Reliabilitas } & \multirow[t]{2}{*}{ Keterangan } \\
\hline & & & $\begin{array}{c}\text { Alpha } \\
\text { Cronbach's }\end{array}$ & Standar & \\
\hline 1 & Promosi jabatan & $\mathrm{Y}$ & 0,840 & 0,6 & Reliabel \\
\hline 2 & Loyalitas & $\mathrm{X} 1$ & 0,753 & 0,6 & Reliabel \\
\hline 3 & Prestasi kerja & $\mathrm{X} 2$ & 0,911 & 0,6 & Reliabel \\
\hline 4 & Senioritas & X3 & 0,777 & 0,6 & Reliabel \\
\hline
\end{tabular}

Sumber : data diproses, 2018.

Pada penelitian yang dilaksanakan, hasil rekapitulasi tanggapan responden terhadap variabel promosi jabatan diukur dengan 5 butir pernyataan dan ditunjukkan pada Tabel berikut.

Menggambarkan tanggapan responden berdasarkan Tabel 5 pada variabel promosi jabatan pada pernyataan butir pertama diperoleh skor rata-rata sebesar 3,97 yang berarti bahwa karyawan bersedia bekerja sama dengan karyawan lainnya. Skor tinggi juga didapatkan pada pernyataan butir kedua, butir ketiga dan butir keempat yang menandakan karyawan mampu menyelesaikan tugas, mampu 
membina karyawan lainnya dan menjalin komunikasi yang baik terhadap karyawan lainnya. Pada pernyataan butir kelima menandakan seluruh karyawan telah memenuhi kualifikasi pada bidangnya.

Tabel 5.

Tanggapan Responden Pada Variabel Promosi Jabatan

\begin{tabular}{|c|c|c|c|c|c|c|c|c|}
\hline \multirow[t]{2}{*}{ Nomor } & \multirow[t]{2}{*}{ Pernyataan } & \multicolumn{5}{|c|}{$\begin{array}{l}\text { Rasio Tanggapan } \\
\text { Responden }\end{array}$} & \multirow[t]{2}{*}{$\begin{array}{l}\text { Rata- } \\
\text { rata }\end{array}$} & \multirow[t]{2}{*}{ Ket. } \\
\hline & & 1 & 2 & 3 & 4 & 5 & & \\
\hline 1 & $\begin{array}{l}\text { Saya bersedia bekerja sama } \\
\text { dengan karyawan lainnya. }\end{array}$ & 0 & 1 & 7 & 62 & 7 & 3,97 & Tinggi \\
\hline 2 & $\begin{array}{l}\text { Cakap dalam menyelesaikan } \\
\text { tugas perusahaan. }\end{array}$ & 0 & 1 & 13 & 45 & 18 & 4,04 & Tinggi \\
\hline 3 & $\begin{array}{l}\text { Saya mampu membina } \\
\text { karyawan yang lain untuk } \\
\text { bekerjasama secara efektif } \\
\text { agar tercapainya sasaran } \\
\text { perusahaan. }\end{array}$ & 0 & 0 & 11 & 49 & 17 & 4,08 & Tinggi \\
\hline 4 & $\begin{array}{l}\text { Saya mampu berkomunikasi } \\
\text { secara efektif untuk } \\
\text { mempersepsi informasi dari } \\
\text { karyawan yang lain dengan } \\
\text { baik sehingga tidak terjadi } \\
\text { miskomunikasi. }\end{array}$ & 0 & 1 & 12 & 49 & 15 & 4,01 & Tinggi \\
\hline 5 & 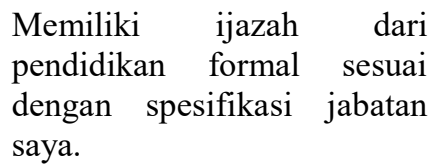 & 0 & 0 & 7 & 53 & 17 & 4,13 & Tinggi \\
\hline & Rata-rata var & e & & & & & 4,04 & Tinggi \\
\hline
\end{tabular}

Sumber : data diproses, 2018.

Ditampilkan pada Tabel 6. hasil jawaban responden terhadap variabel loyalitas pada penelitian ini diukur dengan 5 butir pernyataan. Menggambarkan tanggapan responden berdasarkan Tabel 6. terhadap variabel loyalitas pada pernyataan butir pertama, kedua dan ketiga diperoleh skor rata-rata tinggi yang menandakan karyawan telah mentaati peraturan yang dibuat oleh perusahaan, karyawan mampu melaksanakan tugasnya dengan baik dan karyawan memiliki tanggungjawab untuk menjaga keutuhan perusahaan. Pada pernyataan butir keempat diperoleh skor rata-rata 4,25 yang mendakan karyawan mampu menjalin 
hubungan antar pribadi mereka. Pernyataan butir kelima diperoleh skor rata-rata 4,14 yang artinya karyawan mampu mengerjakan tugas mereka tanpa mengeluh.

Tabel 6.

Tanggapan Responden Pada Variabel Loyalitas

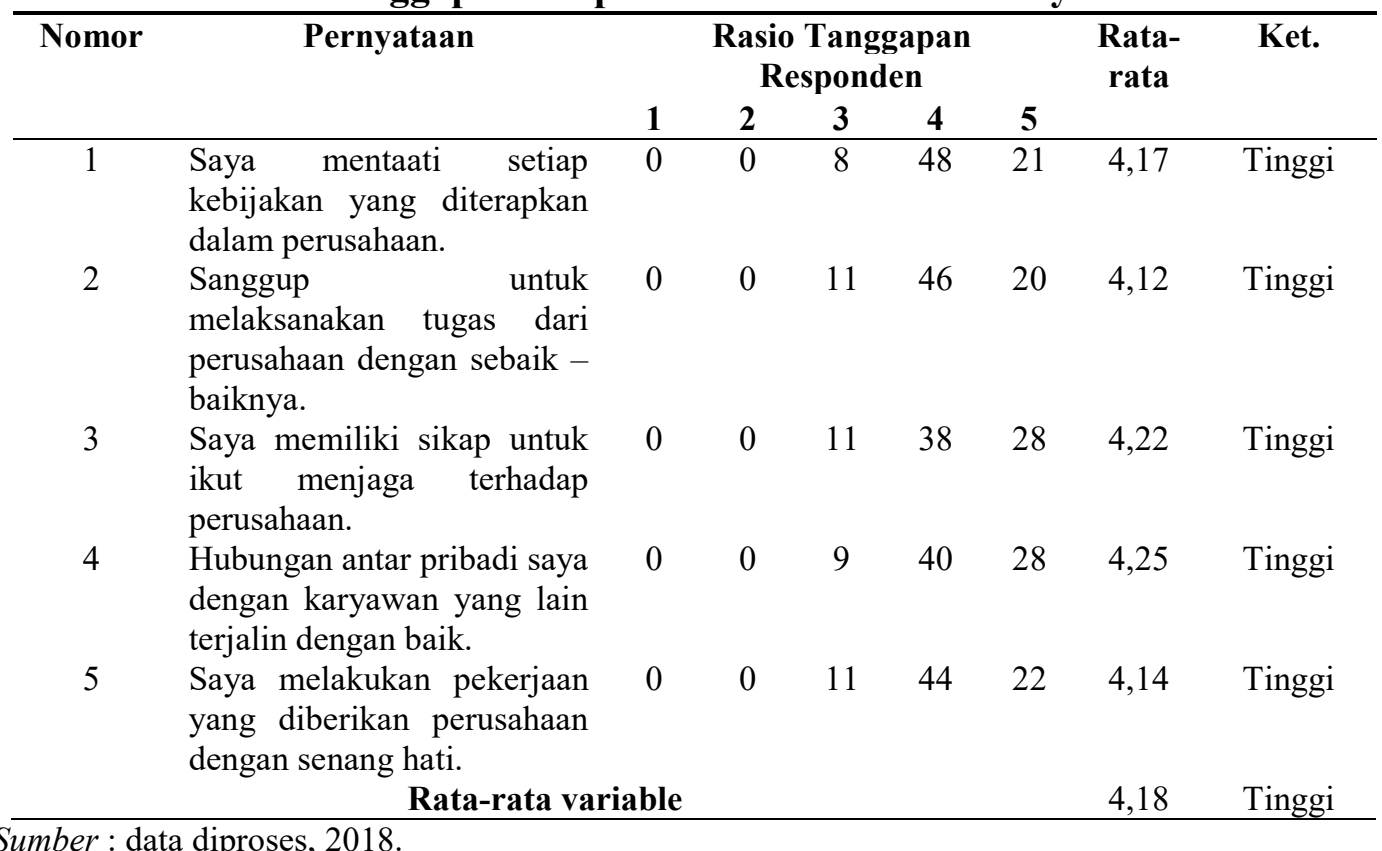

Persepsi responden terhadap variabel prestasi kerja pada penelitian ini diukur dengan 5 butir pernyataan dan ditunjukkan Tabel .

Menggambarkan tanggapan responden berdasarkan Tabel 7. terhadap variabel prestasi kerja pada peryataan butir pertama bahwa karyawan mampu bekerja dengan baik. Pernyataan butir kedua bahwa rata-rata karyawan mengerjakan tugasnya dengan jujur. Skor rata-rata 4,14 dan 3,91 diperoleh pada pernyataan butir ketiga dan keempat yang mendakan bahwa karyawan memiliki perilaku yang baik dan karyawan memiliki kreativitas dalam menyelesaikan pekerjaannya. Pada pernyataan butir kelima menandakan bahwa rata-rata karyawan mampu menghadapi masalah dalam lingkup kerjanya sendiri. 
Tabel 7.

Tanggapan Responden Pada Variabel Prestasi Kerja

\begin{tabular}{|c|c|c|c|c|c|c|c|c|}
\hline \multirow[t]{2}{*}{ Nomor } & \multirow[t]{2}{*}{ Pernyataan } & \multicolumn{5}{|c|}{$\begin{array}{l}\text { Rasio Tanggapan } \\
\text { Responden }\end{array}$} & \multirow[t]{2}{*}{$\begin{array}{c}\text { Rata- } \\
\text { rata }\end{array}$} & \multirow[t]{2}{*}{ Ket. } \\
\hline & & 1 & 2 & 3 & 4 & 5 & & \\
\hline 1 & $\begin{array}{l}\text { Saya menghasilkan kerja } \\
\text { yang baik sesuai dengan } \\
\text { uraian pekerjaan. }\end{array}$ & 0 & 1 & 6 & 54 & 16 & 4,08 & Tinggi \\
\hline 2 & $\begin{array}{l}\text { Tugas yang diberikan oleh } \\
\text { perusahaan saya kerjakan } \\
\text { dengan jujur. }\end{array}$ & 0 & 0 & 13 & 41 & 23 & 4,08 & Tinggi \\
\hline 3 & $\begin{array}{l}\text { Saya berperilaku baik } \\
\text { terhadap seluruh karyawan } \\
\text { sesuai pedoman perusahaan. }\end{array}$ & 0 & 1 & 12 & 44 & 20 & 4,14 & Tinggi \\
\hline 4 & $\begin{array}{l}\text { Mampu mengembangkan } \\
\text { kreativitas dalam } \\
\text { menyelesaikan pekerjaan. }\end{array}$ & 0 & 0 & 12 & 47 & 18 & 3,91 & Tinggi \\
\hline 5 & $\begin{array}{l}\text { Mampu menyelesaikan } \\
\text { masalah yang dihadapi tanpa } \\
\text { bantuan orang lain terlebih } \\
\text { dahulu. }\end{array}$ & 0 & 0 & 12 & 42 & 23 & 3,92 & Tinggi \\
\hline & Rata-rata val & e & & & & & 4,11 & Tinggi \\
\hline
\end{tabular}

Sumber : data diproses, 2018.

Persepsi responden terhadap variabel senioritas dalam penelitian ini diukur dengan 3 butir pernyataan dan ditunjukkan Tabel 8 .

Tabel 8.

Tanggapan Responden Pada Variabel Senioritas

\begin{tabular}{|c|c|c|c|c|c|c|c|c|}
\hline \multirow[t]{2}{*}{ Nomor } & \multirow[t]{2}{*}{ Pernyataan } & \multicolumn{5}{|c|}{$\begin{array}{l}\text { Rasio Tanggapan } \\
\text { Responden }\end{array}$} & \multirow[t]{2}{*}{$\begin{array}{c}\text { Rata- } \\
\text { rata }\end{array}$} & \multirow[t]{2}{*}{ Ket. } \\
\hline & & 1 & 2 & 3 & 4 & 5 & & \\
\hline 1 & $\begin{array}{l}\text { Usia saya lebih senior dari } \\
\text { karyawan yang lain. }\end{array}$ & 0 & 0 & 17 & 50 & 10 & 3,91 & Tinggi \\
\hline 2 & $\begin{array}{l}\text { Saya memiliki wewenang } \\
\text { yang luas di perusahaan ini. }\end{array}$ & 0 & 2 & 15 & 47 & 13 & 3,92 & Tinggi \\
\hline \multirow[t]{2}{*}{3} & $\begin{array}{l}\text { Masa kerja saya di } \\
\text { perusahaan ini yang paling } \\
\text { lama dari karyawan yang } \\
\text { lain. }\end{array}$ & 0 & 4 & 12 & 49 & 12 & 3,90 & Tinggi \\
\hline & Rata-rata var & ible & & & & & 3,91 & Tinggi \\
\hline
\end{tabular}

Sumber : data diproses, 2018.

Menggambarkan persepsi responden berdasarkan Tabel 8 terhadap variabel senioritas pada pernyataan butir pertama diperoleh skor rata-rata sebanyak tiga koma sembilan puluh satu termasuk dalam kategori tinggi yang artinya banyak 
karyawan yang usianya diatas 30 tahun. Pada pernyataan butir kedua rata-rata karyawan merasa memiliki wewenang yang luas atas jabatannya di perusahaan. Nilai rata-rata terendah terdapat pada pernyataan ketiga yaitu masa kerja saya di perusahaan ini yang paling lama dari karyawan yang lain dengan nilai 3,90.

Tabel 9.

Uji Regresi Linier Berganda

\begin{tabular}{|c|c|c|c|c|c|c|}
\hline \multirow{2}{*}{\multicolumn{2}{|c|}{ Model }} & \multirow{2}{*}{\multicolumn{2}{|c|}{$\begin{array}{c}\text { Unstandardized } \\
\text { Coefficients }\end{array}$}} & \multirow{3}{*}{$\begin{array}{c}\text { Standardized } \\
\text { Coefficients } \\
\text { Beta }\end{array}$} & \multirow[t]{3}{*}{$t$} & \multirow[t]{2}{*}{ Sig. } \\
\hline & & & & & & \\
\hline & & $B$ & $\begin{array}{l}\text { Std. } \\
\text { Error }\end{array}$ & & & \\
\hline \multirow[t]{5}{*}{1} & (Constant) & 2,907 & 1,466 & & 1,983 &, 051 \\
\hline & Loyalitas &, 170 & ,072 & ,200 & 2,341 & 022 \\
\hline & Prestasi & ,497 & ,082 & ,535 & 6,082 & ,000 \\
\hline & Kerja & & & & & \\
\hline & Senioritas & ,305 & ,094 & 247 & 3,248 &, 002 \\
\hline
\end{tabular}

Sumber : data diproses, 2018.

Perumpamaan regresi linear berganda yang bisa dirangkai sebagai berikut berdasarkan hasil Tabel 9.

$$
\mathrm{Y}=2,907+0,170 \mathrm{X} 1+0,497 \mathrm{X} 2+0,305 \mathrm{X} 3
$$

Makna dari faktor pengali regresi tersebut bahwa koefisien regresi variabel loyalitas (X1) memiliki pengaruh positif terhadap promosi jabatan. Prestasi kerja (X2) juga memiliki pengaruh positif terhadap promosi jabatan. Senioritas (X3) memiliki tanda positif yang artinya senioritas memiliki pengaruh positif terhadap promosi jabatan. Peningkatan loyalitas, prestasi kerja dan senioritas pada karyawan dapat meningkatkan kesempatan promosi jabatan.

Tabel 10.

Uji Normalitas

\begin{tabular}{ll}
\hline & Unstandardized Residual \\
\hline $\mathrm{N}$ & 77 \\
Kolmogorov-Smirnov Z & 1,227 \\
Asymp. Sig. (2-tailed) & 0,200 \\
\hline Sumber $:$ data diproses, 2018.
\end{tabular}


Perolehan mendapatkan bahwasanya data yang dipakai dalam persamaan regresi merupakan data yang berdistribusi normal, digambarkan pada Tabel 10 besarnya nilai tes statistik sebesar nol koma nol delapan puluh delapan dengan nilai substansial nol koma dua ratus lebih besar dari nol koma nol lima.

Tabel 11.

Uji Multikolinearitas

\begin{tabular}{lll}
\hline Model & \multicolumn{2}{l}{ Colinearity Statistic } \\
\cline { 2 - 3 } & Tolerance & VIF \\
\hline Loyalitas $\left(\mathrm{X}_{1}\right)$ & 0,632 & 1,583 \\
Prestasi Kerja $\left(\mathrm{X}_{2}\right)$ & 0,597 & 1,676 \\
Senioritas $\left(\mathrm{X}_{3}\right)$ & 0,799 & 1,251 \\
\hline Sumber $:$ data diproses, 2018. & &
\end{tabular}

Dijelaskan data yang digunakan dalam persamaan regresi tidak terindikasi gejala multikolienaritas, digambarkan pada Tabel 11 bahwa nilai toleran pada variabel loyalitas, prestasi kerja dan senioritas lebih besar dari nol koma satu serta nilai Variance Inflamation Factor lebih kecil dari sepuluh.

Tabel 12.

Uji Heteroskesdastisitas

\begin{tabular}{|c|c|c|c|c|c|c|}
\hline & \multirow[t]{2}{*}{ Model } & \multicolumn{2}{|c|}{ Unstandardized Coefficients } & \multirow{2}{*}{$\begin{array}{c}\begin{array}{c}\text { Standardized } \\
\text { Coefficients }\end{array} \\
\text { Beta }\end{array}$} & \multirow[t]{2}{*}{$t$} & \multirow[t]{2}{*}{ Sig. } \\
\hline & & $\boldsymbol{B}$ & Std. Error & & & \\
\hline \multirow{4}{*}{1} & (Constant) & 1.907 & .728 & & 2.617 & .011 \\
\hline & Loyalitas & -.063 & .036 & -.249 & -1.759 & .083 \\
\hline & Prestasi Kerja & .059 & .041 & .211 & 1.448 & .152 \\
\hline & Senioritas & -.064 & .047 & -.172 & -1.368 & .176 \\
\hline
\end{tabular}

Data tidak terindikasi gejala heteroskesdastisitas dari Tabel 12 tentang heteroskesdastisitas diperoleh nilai substansial semua variabel bebas lebih besar dari nol koma nol lima. Pada Tabel 13. dapat disimpulkan ditemukan pengaruh signifikan dari loyalitas, prestasi kerja dan senioritas dengan promosi jabatan dan sudah melengkapi kriteria uji kesesuaian. Berdasarkan perolehan sebesar 47.872 
didapat dari nilai F stastistik dan nilai signifikansi sebesar nol koma nol nol nol < nol koma nol lima.

Tabel 13.

Uji kesesuain (Uji F)

\begin{tabular}{lccccc}
\hline Model & $\begin{array}{c}\text { Sum of } \\
\text { Squares }\end{array}$ & df & $\begin{array}{c}\text { Mean } \\
\text { Square }\end{array}$ & F & Sig. \\
& 225,282 & 3 & 75,094 & 47,87 &, $000^{\mathrm{b}}$ \\
Regression & 114,510 & 73 & 1,569 & & \\
Residual & 339,792 & 76 & & & \\
\hline Total & & & &
\end{tabular}

Sumber : data diproses, 2018.

Tabel 14.

Uji $\mathbf{R}^{2}$

\begin{tabular}{lrrrr}
\hline Model & $\boldsymbol{R}$ & $\boldsymbol{R}$ Square & $\begin{array}{c}\text { Model Summary } \\
\text { Adjusted R Square }\end{array}$ & $\begin{array}{c}\text { Std. Error of the } \\
\text { Estimate }\end{array}$ \\
\hline 1 & $.814^{\mathrm{a}}$ & .663 & .649 & 1.25245 \\
\hline
\end{tabular}

Sumber : data diproses, 2018.

Sebesar 64,9 persen variasi promosi jabatan mendapat pengaruh dari loyalitas, prestasi kerja dan senioritas sedangkan sisanya sebesar 35,1 persen mendapat pengaruh dari faktor lain diluar cara penelitian ini, diperoleh dari nilai Adjusted R Square sebesar nol koma enam ratus empat puluh sembilan.

Hasil dari hipotesis pertama, didapatkan nilai signifikan t pada variabel loyalitas sebesar $0,022<0,05$, yang ditunjukkan Tabel 9, mempunyai makna terdapat dampak signifikan secara parsial variabel loyalitas dengan kenaikan jabatan. Loyalitas mempunyai pengaruh terhadap kenaikan jabatan pada PT. Pacto Ltd di Bali terbukti pada hasil hipotesis pertama. Artinya loyalitas yang semakin tinggi dapat meningkatkan promosi jabatan pada PT. Pacto Ltd di Bali.

Hipotesis kedua, didapatkan nilai signifikan $\mathrm{t}$ dilihat dari variabel prestasi kerja sebesar nol koma nol nol nol kurang dari nol koma nol lima yang ditunjukkan Tabel 9. memiliki makna terdapat pengaruh signifikan secara parsial variabel 
prestasi kerja dengan kenaikan jabatan. Prestasi kerja mempunyai pengaruh terhadap promosi jabatan pada PT. Pacto Ltd di Bali terbukti pada hipotesis kedua. Artinya makin baik prestasi kerja karyawan akan meningkatkan pula kesempatan untuk mendapat promosi jabatan pada PT. Pacto Ltd di Bali.

Hipotesis ketiga, berlandaskan Tabel 9. ada terlihat dampak signifikansi parsial variabel prestasi kerja terhadap kenaikan jabatan sebesar 0,002 nol koma nol nol dua kurang dari nol koma nol lima yang diperoleh dari nilai signifikan $\mathrm{t}$ variabel performa kerja. Senioritas mempunyai pengaruh positif terhadap kenaikan jabatan pada PT. Pacto Ltd di Bali terbukti pada hasil hipotesis ketiga. Artinya senioritas yang semakin tinggi dapat meningkatkan promosi jabatan pada PT. Pacto Ltd di Bali.

Pengujian dari hipotesis pertama membuktikan loyalitas memiliki pengaruh positif terhadap promosi jabatan pada pada PT. Pacto Ltd di Bali. Meningkatnya loyalitas yang dimiliki karyawan dalam bekerja maka kesempatan untuk mendapatkan promosi jabatan akan kian tinggi pula. Penelitian Hamzah dkk., (2013), penelitian Soegandhi dkk. (2013), penelitian Mandiangan dan Agoes (2015), penelitian Turkyilmaz et al. (2011), penelitian Prabudi (2015) dan penelitian Mirayanti (2015) selaras dengan penelitian ini.

Pengujian pada hipotesis kedua mendapatkan perolehan prestasi kerja mempunyai sebuah pengaruh terhadap promosi jabatan pada PT. Pacto Ltd di Bali. Hasil ini menunjukkan bahwa prestasi kerja yang dapat dicapai oleh setiap karyawan merupakan salah satu penunjang bahwa promosi jabatan akan diperoleh. Penelitian Cressida dkk. (2013), penelitian Sasmita dan Ni (2016), penelitian 
Medhiantari dan Made (2014), penelitan Hayati (2015) dan penelitian Siska dan Suryalena (2017) selaras dengan penelitian ini.

Hasil pengujian hipotesis ketiga membuktikan bahwa senioritas mempunyai pengaruh positif signifikan terhadap promosi jabatan pada pada PT. Pacto Ltd di Bali. Hasil ini membuktikan bahwa lama bekerja seseorang ditunjukkan dengan tingkat senioritas sehingga semakin senior seorang karyawan maka semakin besar kesepatan untuk mendapatkan promosi jabatan. Penelitian Edmondson (2012), penelitian Yeh dan Jiin (2012), penelitian Andhara dkk., (2015) dan penelitian Purwaningsih dan Betty (2017) selaras dengan penelitian ini.

\section{SIMPULAN DAN SARAN}

Berikut adalah kesimpulan perolehan dari penelitian yang telah dijabarkan: (1) Loyalitas berpengaruh positif terhadap promosi jabatan pada PT. Pacto Ltd di Bali. Hasil tersebut mengindikasikan kesempatan untuk mendapat promosi jabatan akan semakin tinggi jika seseorang memiliki loyalitas tinggi. (2) Prestasi kerja mempunyai pengaruh positif terhadap promosi jabatan pada PT. Pacto Ltd di Bali. Hasil tersebut mengindikasikan makin baik prestasi yang dimiliki dan dihasilkan karyawan, maka akan makin tinggi kesempatan untuk mendapatkan kenaikan jabatan. (3) Senioritas mempunyai pengaruh positif terhadap promosi jabatan pada PT. Pacto Ltd di Bali. Hasil tersebut mengindikasikan jika seseorang karyawan dalam perusahaan tergolong karyawan senior maka kesempatan untuk mendapatkan promosi jabatan akan makin tinggi.

Berikut adalah saran yang dapat direkomendasikan berdasarkan hasil dari analisis dan pembahasan: (1) PT. Pacto Ltd di Bali diharapkan mampu 
memperhatikan karyawannya agar terjalin kerja sama yang baik antar karyawan dan perusahaan dan mampu meningkatkan komunikasi yang baik antar karyawan dan perusahaan agar tidak terjadi kesalahan persepsi. Misalnya dengan cara meningkatkan komunikasi yang baik, membangun kepercayaan antar karyawan dan melakukan gathering. (2) PT. Pacto Ltd di Bali sebaiknya mengadakan pelatihan atau seminar kepada karyawannya agar kemampuan kinerja para karyawan terus meningkat sehingga segala tugas dari perusahaan dapat dilakukan dengan sebaik mungkin dan mengadakan sosialisasi kebijakan atau peraturan agar karyawan bisa mentaatinya dengan baik. (3) PT. Pacto Ltd di Bali diharapkan agar mempertimbangkan masa kerja karyawan, sehingga semua karyawan senior mempunyai peluang yang sama untuk dipromosikan pada jabatan yang lebih tinggi.

\section{REFERENSI}

Andhara, Sona De., Hamidah Nayati Utami, \& Yuniadi Mayowan. (2015). Pengaruh Senioritas Dan Loyalitas Terhadap Promosi Jabatan (Studi Pada Karyawan Departemen Kebijakan Ekonomi Dan Moneter Bank Indonesia Jakarta). Jurnal Administrasi Bisnis, 2(1), 1-9.

Andriani, Yuni. (2018). Pengaruh Penilaian Prestasi Kerja Karyawan Terhadap Promosi Jabatan Pada PT. Noor Asni Naga Jaya (Rayon Ilir) Samarinda. EJurnal Administrasi Bisnis Fakultas Ilmu Sosial dan Ilmu Politik Universitas Mulawarman, 6 (1), 90-101.

Anyim, Francis C., Cyril Oseloka Ikemefuna, \& A. Oluseyi Shadare. (2011). Internal Versus External Staffing in Nigeria: Cost-Benefit Implication. Journal of Management and Strategy, 2(4), 35-42.

Aryani, Yunita., Ratih Maria Dhewi, \& Sjafri Mangkuprawira. (2010). Analisis Pengaruh Sistem Promosi Jabatan terhadap Kinerja Karyawan pada Divisi Human Resources and General Affairs PT Indocement Tunggal Prakarsa, Tbk Citeureup. Jurnal Manajemen dan Organisasi, 1(3), 171-186.

Breevaart, Kimberley \& Arnold B. Bakker. (2015). Leader Member Exchange, Work Engagement, and Job Performance. Journal of Managerial Psychology, 30(7), 754-770. 
Cressida, Farda Dwi., Al-Musadieq, \& Soe'oed Hakam. (2013). Pengaruh Prestasi Kerja Karyawan Terhadap Promosi Jabatan. Jurnal Administrasi Bisnis, $3(1), 1-8$.

Dar, Laiba., Anum Akmal, Muhammad Akram Naseem \& Kashif Ud Din Khan. (2011). Impact of Stress on Employees Job Performance in Business Sector of Pakistan. Global Journal of Management and Business Research, 11(6), $1-5$.

Edmondson, Vickie Cox. (2012). Reflections from a Black Female in the Promotion and Tenure Process. Gender in Management: An International Journal, 27(5), 327-341.

Elfianto. (2015). Pengaruh Penilaian Prestasi Kerja Pegawai Terhadap Promosi Jabatan Pegawai di BPS Provinsi Sumatera Barat. Jurnal Manajemen dan Kewirausahaan, 6(3), 18-36.

Fernandes, Daphne T., \& Vijay Pithadia. (2012). A Stuty On The Effectiveness Of Performance Appraisal System At Suzlon. International Journal of Management Research and Review, 2(13), 1001-1012.

Ghozali, Imam. (2013). Aplikasi Analisis Multivariate dengan Program IBM SPSS 19. Semarang: Badan Penerbit Universitas Diponegoro.

Gupta, Nina \& Jason D. Shaw. (2014). Employee Compensation: The Neglected Area of HRM Research. Human Resource Management Review, 24(4), 1-4.

Hamzah, Febrian Muriko., Mochammad Al Musadieq \& M. Soe'od Hakam. (2013). Pengaruh Senioritas dan Loyalitas Terhadap Promosi (Studi pada Karyawan PT. Pembangunan Perumahan DVO III Surabaya. Jurnal Administrasi Bisnis, 6(2), 1-8.

Hasibuan, Malayu S.P. (2013). Manajemen Sumber Daya Manusia. Jakarta: Bumi Aksara.

Hasibuan, Malayu S.P. (2014). Manajemen Dasar, Pengertian, dan Masalah. Jakarta: Bumi Aksara.

Hayati, Diana. (2015). Analisis Pengaruh Prestasi Kerja Pegawai Tetap Terhadap Promosi Jabatan pada PT. PLN (PERSERO) Area Banjarmasin. Jurnal Ekonomi dan Bisnis, 8(1), 20-32.

Heryati, Agustina. (2016). Pengaruh Kompensasi Dan Beban Kerja Terhadap Loyalitas Karyawan Di Departemen Operasi PT. Pupuk Sriwidjaja Palembang. Jurnal Ecoment Global, 1(2), 56-75. 
Iqbal, Anam., Muhammad Sajid Tufail \& Rab Nawaz Lodhi. (2015). Employee Loyalty and Organizational Commitment in Pakistani Organizations. Global Journal Of Human Resource Management, 3(1), 1-11.

Khan, Taslim \& G.P.Mishra. (2013). Promotion As Job Satisfaction, A Study on Colleges Of Muscat, Sultanate of Oman. European Journal of Business and Management, 5(5), 56-62.

Khuong, Mai Ngoc \& Bui Diem Tien. (2013). Factors Influencing Employee Loyalty Directly and Indirectly Through Job Satisfaction - A Study of Banking Sector in Ho Chi Minh City. International Journal of Current Research and Academic Review, 1(4), 81-95.

Malik, Muhammad Ehsan., Rizwan Qaiser Danish \& Yasin Munir. (2012). The Impact of Pay and Promotion on Job Satisfaction: Evidence from Higher Education Institutes of Pakistan. American Journal of Economics, 10(2), 69.

Mandiangan, Eliana Febisica \& Agoes Ganesha Rahyuda. (2015). Pengaruh Prestasi Kerja, Senioritas, dan Loyalitas Terhadap Promosi Jabatan pada Discovery Kartika Plaza Hotel Bali. E-Jurnal Manajemen Unud, 4(5), 13861405.

Manullang, Mariot A. (2011). Manajemen Personalia (Cetakan Ketiga). Jakarta: Gadjah Mada University Press.

Marion, Elisa Carolina, Ratna Handayani \& Natsumi Koda. (2012). Pengaruh Sistem Senioritas atau Nenkojoretsu Terhadap Perkembangan Karir Karyawan Lokal Berpendidikan S1 di perusahaan Jepang di Indonesia. Jurnal Lingua Cultura, 6(2), 207-213.

Matasik, Christian P., Adolfina \& Genita G. Lumintang. (2017). Pengaruh Komunikasi Dan Sikap Kerja Terhadap Prestasi Kerja Karyawan PT. Bank Negara Indonesia Kantor Cabang Manado. Jurnal Emba, 5(2), 613-623.

Maulana, Addin. (2016). Pengaruh Kunjungan Wisatawan Mancanegara dan Perjalanan Wisatawan Nusantara Terhadap Penyerapan Tenaga Kerja Sektor Pariwisata di Indonesia. Jurnal Kepariwisataan Indonesia, 11(1), 119-144.

Medhiantari, Ida Ayu Nithya \& Made Yuniari. (2014). Pengaruh Prestasi Kerja dan Pengalaman Kerja Terhadap Promosi Jabatan pada PT. Bank Rakyat Indonesia (Persero) Tbk. Cabang Gajah Mada Denpasar. E-Jurnal Manajemen Unud, 3(7), 2035-2049. 
Mirayanti. (2015). Pengaruh Loyalitas, Pendidikan dan Pelatihan Serta Kinerja Terhadap Promosi Jabatan Pada Kantor Sekretariat Daerah Kabupaten Tolitoli. E-Jurnal Katalogis, 3(1), 95-104.

Muamarizal, Said., Samsir \& Marzolina. (2015). Pengaruh Pengalaman Kerja Dan Penilaian Prestasi Kerja Terhadap Pengembangan Karir Karyawan Pada PT. Jasaraharja Putera Cabang Pekanbaru. Jom Fekon, 2(1), 1-21.

Naveed, Asvir., Ahmad Usman \& Fatima Bushra. (2011). Promotion: A Predictor of Job Satisfaction A Study of Glass Industry of Lahore (Pakistan). International Journal of Business and Social Science, 2(16), 301-305.

Ong, Derek., Victor Ong, Lim Hoong Zhang, Puah Shin Huey \& Tiong Siew Hie. (2014). Expressions of Fresh Graduates: Employee Loyalty in Malaysia. World Journal of Management, 5(2), 92-106.

Prabowo, Bastian., Mochammad Al Musadieq \& Ika Ruhana. (2016). Pengaruh Promosi Jabatan Terhadap Motivasi Kerja Dan Prestasi Kerja (Studi Pada Karyawan PT. Telkom Indonesia Witel Jatim Selatan Malang). Jurnal Administrasi Bisnis, 32(1), 106-113. Prabudi, I Made \& I Wayan Suana. (2015). Pengaruh Kepemimpinan Transformasional Dan Loyalitas Karyawan Terhadap Prestasi Kerja Karyawan pada Koperasi Danu Jaya Tabanan. E-Jurnal Manajemen Unud, 4(1), 192-208.

Pratama, Dhanang Bayu., Bambang Swasto Sunuharyo \& M. Soe'oed Hakam. (2013). Pengaruh Insentif Dan Promosi Terhadap Prestasi Kerja (Studi Pada Karyawan PT PLN (Persero) Distribusi Jawa Timur Unit Pelayanan dan Jaringan Kabupaten Sampang). Jurnal Administrasi Bisnis, 2(2), 76-81.

Pratimi, Diah Mahayuni. (2016). Pengaruh Loyalitas dan Prestasi Kerja Terhadap Promosi Jabatan Pada The Jayakarta Bali Hotel. E-Jurnal Manajemen Unud, 5(11), 7446-7472.

Purwaningsih, Amalia \& Betty Magdalena. (2017). Pengaruh Senioritas Dan Prestasi Kerja Terhadap Promosi Jabatan Pada Karyawan. Jurnal Bisnis Darmajaya, 3(1), 14-26.

Safitri, Rahmadana. (2015). Pengaruh Kompensasi Terhadap Loyalitas Karyawan PT. Putera Lautan Kumala Lines Samarinda. E-Journal Administrasi Bisnis, 3(3), 650-660.

Saputra, Agus Tunggal., I Wayan Bagia \& Ni Nyoman Yulianthin. (2016). Pengaruh Kepuasan Kerja dan Loyalitas Karyawan Terhadap Kinerja Karyawan. E-Journal Bisma Universitas Pendidikan Ganesha Jurusan Manajemen, 4(1), 1-8. 
Sari, Dewi Comala. (2015). Pengaruh Lingkungan Kerja dan Senioritas Terhadap Produktivitas Kerja Dosen di Jurusan Administrasi Niaga Politeknik Negeri Medan. Jurnal Ilmiah Research Sains, 1(3), 1-10.

Sasmita, Ida Ayu Gita Dwi \& Ni Wayan Mujiati. (2016). Pengaruh Prestasi Kerja dan Kompetensi Karyawan Terhadap Promosi Jabatan pada INNA Sindhu Beach Hotel Sanur Denpasar. E-Jurnal Manajemen Unud, 5(8), 4807-4834.

Siagian, Sondang P. (2012). Manajemen Sumber Daya Manusia. Jakarta: Bumi Aksara.

Siska, Alia Dwi \& Suryalena. (2017). Pengaruh Prestasi Kerja dan Loyalitas Terhadap Promosi Jabatan (Studi Pada Karyawan Bagian Sales Executive and Counter Pada PT. Agung Automall Cabang Pekanbaru). Jurnal Online Mahasiswa Fakultas Ilmu Sosial dan Ilmu Politik Universitas Riau, 4(2), 114.

Sobieralski, Jayme \& Cynthia R. Nordstrom. (2012). An Examination of Employee Layoffs and Organizational Justice Perceptions. Journal of Organizational Psychology, 12(3), 11-20.

Soegandhi, Vannecia Marchelle., Eddy M. Sutanto \& Roy Setiawan. (2013). Pengaruh Kepuasan Kerja dan Loyalitas Kerja Terhadap Organizational Citizenship Behavior pada Karyawan PT. Surya Timur Sakti Jatim. Jurnal Agora, 1(1), 1-12.

Sugiyono. (2015). Metode Penelitian Pendidikan Pendekatan Kuantitatif, Kualitatif, dan R\&D. Bandung: Alfabeta.

Suharti, Lieli \& Dendy Suliyanto. (2012). The Effects of Organizational Culture and Leadership Style toward Employee Engagement and Their Impacts toward Employee Loyalty. World Review of Business Research, 2(5), 128139.

Suyana Utama, Made. (2012). Buku Ajar Aplikasi Analisis Kuantitatif (Edisi Keenam). Denpasar: Fakultas Ekonomi Universitas Udayana.

Thanos, Casie Angela., Sifrid S. Pangemanan \& Farlane S. Rumokoy. (2015). Pengaruh Kepuasan Pekerjaan dan Motivasi Karyawan Terhadap Loyalitas Karyawan (Studi Kasus PT Kimia Farma Apotek Di Samratulangi, Manado). Jurnal Berkala Ilmiah Efisiensi, 15(4), 313-321.

Turkyilmaz, Ali., Gulsen akman, Coskun Ozkan, \& Zbigniew Pastuszak. (2011). Empirical Study of Public Sector Employee Loyalty and Satisfaction. Industrial Management and Data System, 111(5), 675-696. 
Tuwei J. G., Matelong K. N., Boit S. R., \& Tallam K. Z. (2013). Promotion Opportunity on Employee Career Change Decision: The Case of a Selected Learning Institution in Kenya. International Journal of Business and Management, 8(18), 53-62.

Wan, Hooi Lai. (2013). Employee Loyalty at the Workplace: The Impact of Japanese Style of Human Resource Management. International Management Journals, 3(1), 1-17.

Yeh, Chiou-Nan \& Jiin Wang. (2012). Seniority, Discipline, and Faculty Salaries: A Case Study. American Society of Business and Behavioral Sciences, 19(1), 932-937. 